Chirurgia (2021) 116: 466-472

No. 4, July - August

Copyright $\odot$ Celsius

http://dx.doi.org/10.21614/chirurgia.116.4.466

\title{
The Importance of Route Anatomic Variants of the Common Hepatic Artery
}

\author{
Șerban Marinescu', Bogdan Tănase ${ }^{1}$, Ciprian Cirimbei ${ }^{1,2}$, Laurențiu Simion ${ }^{1,2^{*}}$ \\ 1"Prof. Dr. Al. Trestioreanu” Institute of Oncology, Bucharest, Romania \\ 2"Carol Davila" University of Medicine and Pharmacy, Bucharest, Romania
}

*Corresponding author:

Associate Professor Dr. Laurentiu

Simion, M.D., Ph.D.

"Carol Davila" University of Medicine and Pharmacy - Bucharest, Romania

"Prof. Dr. Al. Trestioreanu" Institute of Oncology, Bucharest, Romania

252 Fundeni Road

E-mail: lasimion@yahoo.com

\section{Rezumat \\ Importanț variantelor anatomice de traseu ale arterei hepatice comune}

Introducere: În literatură sunt descrise numeroase variante de vascularizatie la nivelul trunchiului celiac şi arterei mezenterice superioare. Anatomia zonei este un subiect de studiu, având în vedere impactul potențial asupra tehnicilor chirurgicale şi riscul de a genera incidente/accidente intraoperatorii sau complicatiii.

Material şi Metodă:Am efectuat un studiu retrospectiv unicentric, în Clinica de Chirurgie 1 a Institutului Oncologic "Prof. Dr. Al. Trestioreanu" Bucureşti, pe un interval de 11 ani, privind incidența acestei rare anomalii de traseu a arterei hepatice comune, incidență ce este evaluată în literatură la aproximativ $0,1 \%$. Studiul a avut două componente, pe de o parte verificarea înregistrărilor din documentele medicale (condici de operații, în principal), pe de altă parte discuții de tip focus-grup cu cei 19 medici chirurgi ai secției privind experiența operatorie personală a fiecăruia. Am identificat două cazuri în care s-a întâlnit această anomalie de traseu al arterei hepatice comune, adică variantă de traseu retroportal. Cazurile sunt complet documentate, inclusiv imagistic şi sunt prezentate pe scurt.

Rezultate: Variantele anatomice ale trunchiului celiac reprezintă un subiect extrem de studiat, având în vedere implicațiile majore în chirurgia hepato-bilio-pancreatică şi a transplantului hepatic. Variantele de traseu sau de origine ale arterei hepatice pot fi cauza a numeroase incidente şi accidente atât în chirurgia oncologică hepato-bilio-pancreatică, dar şi în cea a traumei. Nerecunoaşterea variantelor anatomice, preoperator sau intraoperator, se poate 
solda cu leziuni vasculare importante, mai ales ale venei porte, ce pot complica foarte mult timpul de rezectie.

Concluzii: Variantele de traseu ale arterei hepatice sunt deosebit de importante în chirurgia de transplant hepatic, chirurgia oncologică hepato-bilio-pancreatică sau gastrică, procedurile de radiologie intervențională, dar şi în chirurgia traumei, mai cu seamă a leziunilor penetrante abdominale supramezocolice. Ideal este că aceste variante anatomice să fie recunoscute preoperator şi astfel să se poată adopta tehnica de abord chirurgical cea mai potrivită.

Cuvinte cheie: variante anatomice, artera hepatică comună, traseu retroportal

\section{Abstract}

Introduction:Variants of vascularization in the celiac and upper mesenteric artery are described in the dedicated literature. The anatomy of this area is a subject of interest, considering the potential techniques and the risk of generating intraoperative incidents/accidents or complications.

Material and Method: We have conducted a unicentric retrospective study, in the Surgery Clinic No.1 of "Prof. Dr. Al. Trestioreanu" Institute of Oncology from Bucharest, on an 11-year interval of time, concerning the occurrence of this rare route-related anomaly of the common hepatic artery, incidence which is evaluated in the dedicated literature at about $0.1 \%$. The study consisted of two components, namely the relevant medical records, on the one hand and focus-group discussions with the 19 surgeons of our department regarding their personal operating experiences, on the other hand.

We have identified two cases where this route abnormality of the common hepatic artery, i.e. the retroportal route variant, has been encountered. These two cases are fully documented, including CT-scan and intraoperative images, and they are briefly presented hereinafter.

Results: Anatomical variants of the celiac trunk represent an extremely researched topic, considering the major implications in hepato-pancreato-biliary surgery and liver transplantation. Variants of route or origin of the hepatic artery can be the cause of numerous incidents and accidents in hepato-pancreato-biliary oncology surgery, but also in that of trauma. Non-recognition of anatomical, preoperative or intraoperative variants can result in important vascular lesions, especially of the portal vein, which can greatly complicate the resection time.

Conclusions: Route variants of the hepatic artery are particularly important in liver transplantation, hepato-pancreato-biliary or gastric oncology surgery, interventional radiology procedures, but also in trauma surgery, especially in case of supramesocolic abdominal penetrating lesions. It would be ideal for these variants to be recognized before surgery, so that the most appropriate surgical technique can be adopted.

Key words: anatomical variants, common hepatic artery, retroportal route

\section{Introduction}

The anatomy of the celiac region and variations in vascularization in the celiac trunk and upper mesenteric artery are a subject of study, many variants of both origin and route being described, with different impact on surgical techniques, given that the common hepatic artery (CHA) and the proper hepatic artery
(PHA) are important intraoperative landmarks for dissection in the liver pedicle.

Common or proper hepatic artery with retroportal routes are rare variants, but they can cause difficulties and intraoperative accidents.

The first variations of the celiac trunk were described by Haller in 1756 and Michels in 1966 and Hiatt in 1994 described anatomical 
variations of origin and branching of the celiac trunk and upper mesenteric artery (AMS) $(1,2)$. A comparison of the two classifications can be seen in Table 1 .

To be familiar with possible anatomical variants of the hepatic artery is of vital importance in hepato-pancreato-biliary surgery, liver transplantation, trauma, but also in interventional radiology $(3,4)$. Lack of familiarity with such anatomical variants predisposes to the occurrence of accidents and incidents, both in surgery and percutaneous procedures.

\section{Material and Method}

We have conducted a unicentric retrospective analysis, in the Surgery Clinic 1 of "Prof. Dr. Al. Trestioreanu" Institute of Oncology, over an interval of 11 years, respectively January 2010 - December 2020, evaluating both medical records and surgeons' personal experience.

The study of medical records mainly involved the analysis of the operating protocols, focusing on procedures addressed to the hepato-pancreato-biliary or gastric pathology. It should be noted that during the study period the surgical procedures were mostly scheduled and oncological. No liver transplant surgery or interventional radiology procedures were performed in the clinic.

At the same time, we also conducted a retrospective focus group study, interviewing 19 senior general surgeons who were active during the time period of the study, in the Surgery Clinic 1 of the "Prof. Dr. Al. Trestioreanu" Institute of Oncology from Bucharest. The questions concerned personal cases, regarding the anatomical variants of the common hepatic artery, found in interventions in the hepato-pancreato-biliary sphere. Given the rarity of these cases, it is extremely likely that the surgeons, if they have encountered such anatomical variants, they will remember.

Pursuant to these analyses, we identified two cases in which we could document route variants of the common liver artery, namely the retro-portal route.
Table 1.

\begin{tabular}{lcc}
\hline Anatomic variant & $\begin{array}{c}\text { Michels } \\
\text { classification }\end{array}$ & $\begin{array}{c}\text { Hiatt } \\
\text { classification }\end{array}$ \\
\hline normal & Type I & Type I \\
\hline LHA from LGA & Type II & Type II \\
\hline RHA from SMA & Type III & Type III \\
\hline LHA from LGA and RHA from SMA & Type IV & Type IV \\
\hline LHA accessory from LGA & Type V & Type II \\
\hline RHA accessory from SMA & Type VI & Type III \\
\hline LHA accessory from LGA and RHA & Type VII & Type IV \\
accessory from SMA & & \\
\hline accessory LHA from LGA and RHA & Type VIII & Type IV \\
from SMA & & \\
\hline CHA from SMA & Type IX & Type V \\
\hline LHA and RHA from LGA & Type X & - \\
\hline CHA from the aorta & - & Type VI \\
\hline LHA - left hepatic artery & & \\
RHA - right hepatic artery & & \\
SMA - superior mesenteric artery & & \\
LGA - left gastric artery & & \\
CHA - common hepatic artery & &
\end{tabular}

\section{Results}

The retrospective unicentric study enabled us to identify, within the 11-year interval, only two cases of common hepatic artery with retroportal route, cases that we could fully document, including by means of relevant images. It should be mentioned, one more time, that the specificity of the surgery performed in the clinic during the said period is scheduled oncologic surgery.

The first patient, aged 61, with a history of laparoscopic splenectomy 2 years ago for autoimmune hemolytic anemia, was hospitalized in our clinic for epigastric pain, loss of weight, and lack of appetite. Superior digestive endoscopy revealed the presence of a vegetative tumor of the gastric body. The CT scan raised suspicion of invasion of the pancreatic tail, but without liver or peritoneal metastases.

Intraoperatively, a gastric body tumor was found, invading the pancreatic tail, without liver or peritoneal metastases. Total gastrectomy, distal pancreatectomy and regional lymphadenectomy were performed. The hepatic pedicle was approached, identifying the proper hepatic artery, which was placed to the right of the portal vein. Continuing the dissection, the retroportal route of the common hepatic artery was identified 


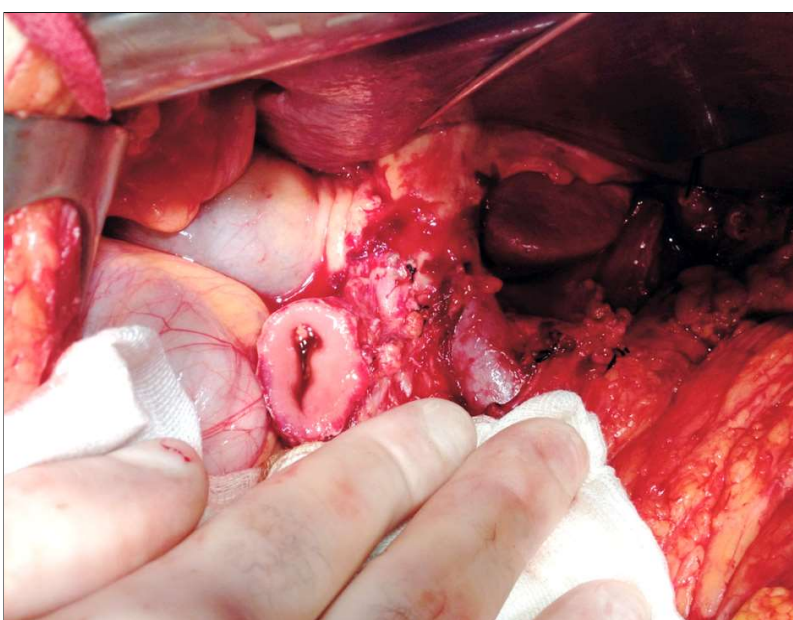

Figure 1. Intraoperative image. The resection time is over. The caudate lobe, the sectioned duodenum, the portal vein, the common hepatic artery and the proper hepatic artery can be observed

(Figs. 1, 2). Careful examination of the preoperative CT scan revealed the anomaly of the route of the common hepatic artery (Fig. 3). In the postoperative evolution, a pancreatic leak occurred, but it was resolved by means of conservative treatment.

The second patient identified, aged 26, came for morning hypoglycemia, which turned out to be basal hyperinsulinemia. The CT scan showed a $3 \mathrm{~cm}$ pancreatic head tumor, native isodense, postcontrast hyper dense. The CT

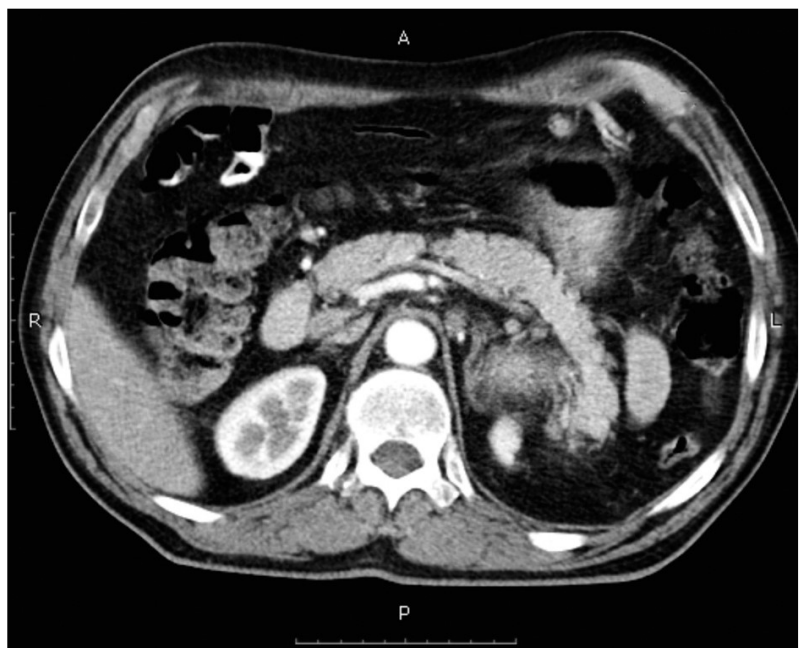

Figure 3. Preoperative CT scan with contrast substance. The hepatic artery with retroportal route is observed

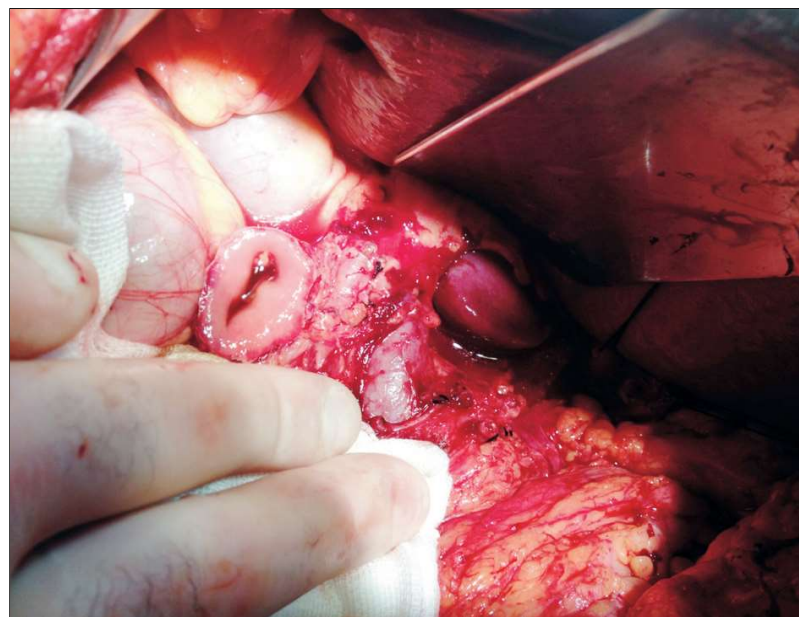

Figure 2. Intraoperative image. At the time of the approach of the celiac trunk and the common hepatic artery, in order to achieve regional lymphadenectomy, the retroportal trajectory of the common hepatic artery is observed

scan also reveals the hepatic artery with retroportal route (Fig. A).

The surgical intervention allowed the enucleation of the tumor formation, with intraoperative histo-pathological examination, which revealed the presence of malignant cells (Figs. 5, 6, 7). The intervention continued with pancreaticoduodenectomy. During the maneuvers to identify the gastro-duodenal artery, the retroportal common hepatic artery was found, with the appearance of the gastro-

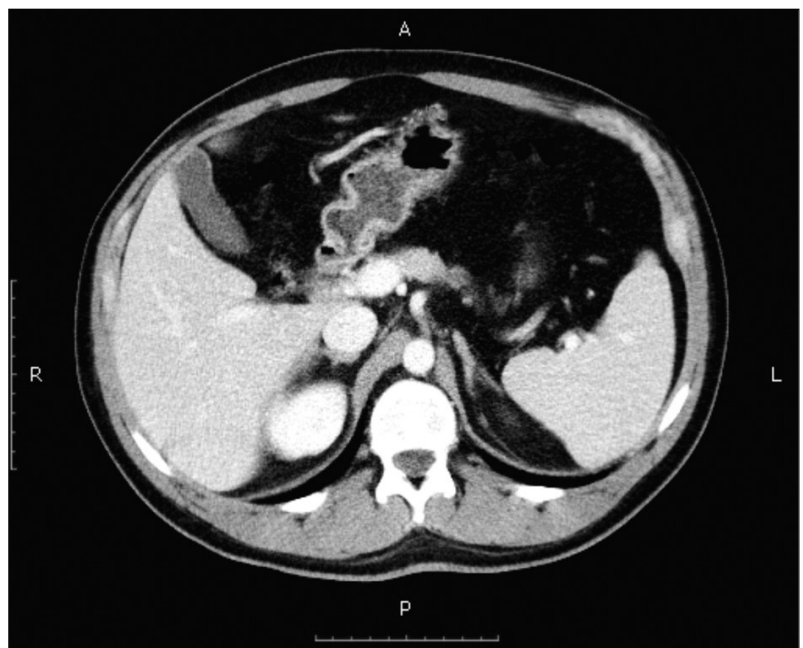

Figure 4. CT scan with preoperative contrast substance, representing the retroportal route of the common hepatic artery 


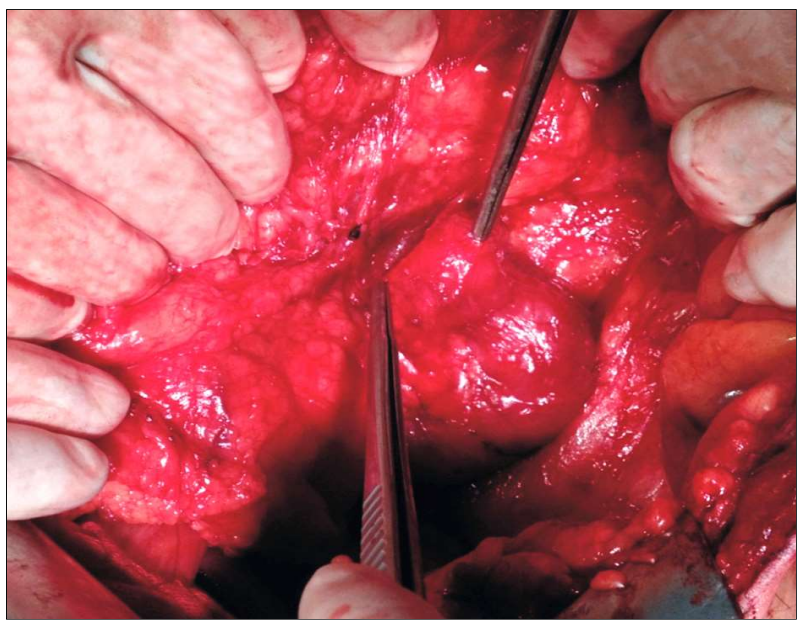

Figure 5. Intraoperative image. The head of the pancreas is observed, upon which a tumor of approx. $3 \mathrm{~cm}$. can be identified, tumor which is relatively well delineated from the rest of the parenchyma

duodenal artery in the right side of the portal vein (Fig. 8). The restoration of digestive continuity was achieved by termino-terminal pancreatico-jejunal anastomosis by intubation, hepatico-jejunal anastomosis terminolateral performed by Witzel technique and precolic termino-lateral gastro-entero anastomosis. The patient's post-surgery evolution was uneventful.

\section{Discussions}

The incidence of anatomical variants in the hepatic artery is very high, its level amounting to around 39\%, according to Saba $\mathrm{L}$ and Mallanani G (5). The study published by the two authors in 2011 is a radiological one and took into account 1910 patients, investigated between 2004 and 2009.

A search made in the Pub Med database by entering the keywords: "retroportal common liver artery" led to a number of 26 results, of which only 5 were significant. Thus, we have identified in the literature 13 cases of common hepatic artery with retroportal route.

Anatomical variants of the celiac trunk are a highly researched topic, considering the major implications in hepato-bilio-pancreatic surgery and liver transplantation.

Thus, in 1969 Vandamme JP, Bonte J and

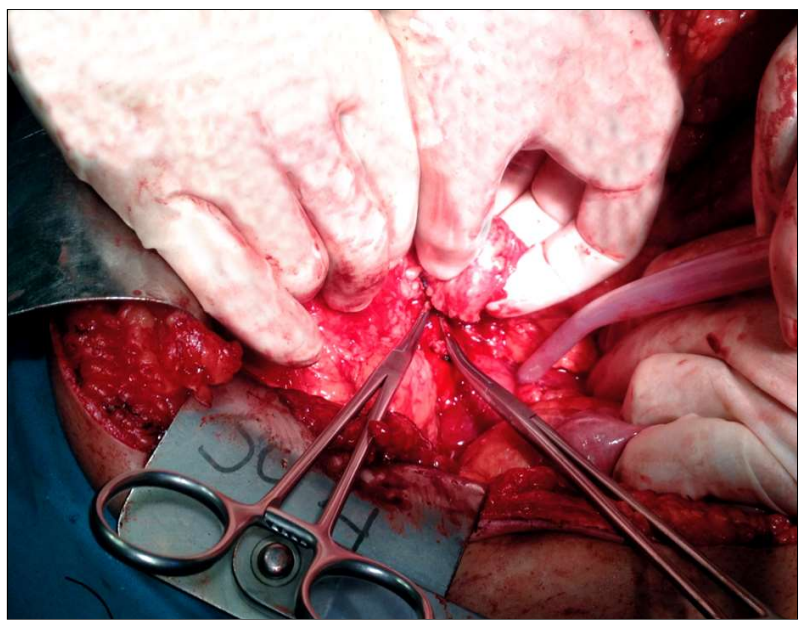

Figure 6. The tumor is resected and then sent to the laboratory for intraoperative hystopathologic examination

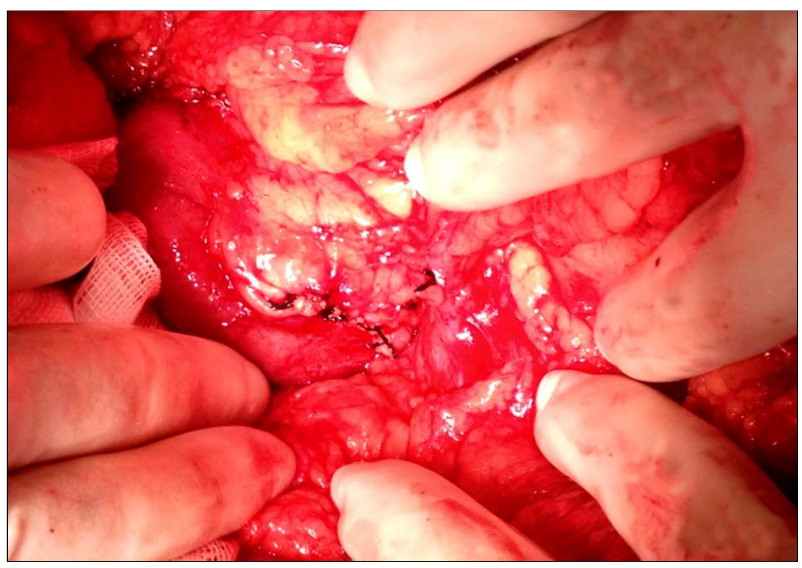

Figure 7. Intraoperatory aspect after the resection of the cephalopancreatic tumor

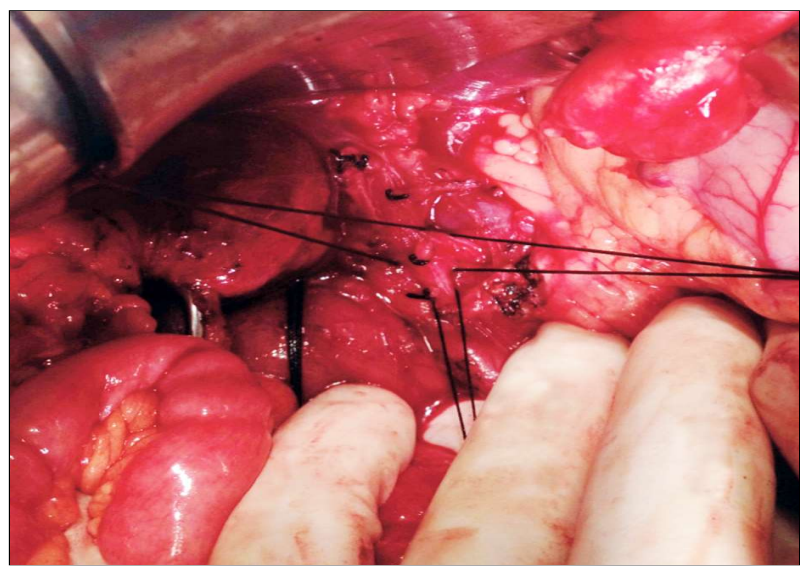

Figure 8. The common hepatic artery appears from under the portal vein, giving rise immediately to the gastroduodenal artery 
Van der Scheueren G. published an anatomical study of hepatic artery variations, carried out by analysis of a number of 156 cadavers (6) and in 1971 the same topic was treated by Suzuki et al. based on 200 patients, studied angiographically (7).

The most important radiological study was published by Song et al. in 2010 and was performed on a number of 5,002 patients. The results showed normal anatomy of the celiac trunk in $89.1 \%$ of cases and 13 possible anatomical variants (8). The common hepatic artery with celiac origin was found in 4,763 patients; in case of 7 of the said patients, variants of trajectory were identified: retroportal route -6 cases, intrapancreatic route -1 case. So, according to this study, the hepatic artery with retroportal route is a very rare eventuality, found in $0.1 \%$ of cases.

In 2013, another radiological study, which took into account 600 patients, revealed normal anatomy of the celiac trunk in $91 \%$ of cases (546 cases), with normal pre-portal route of the common hepatic artery in $97.78 \%$, with the retro-portal route being found in 7 patients (1.1\%) (4).

Another anatomical study, conducted on 45 cadavers between July 2010 and April 2011 in Brazil, revealed variants of the liver artery in approx. $40 \%$ of cases (9). After having studied a number of 200 bodies, Michels identified the presence of anatomical variants in $45 \%$ of cases (10).

Other data from the literature dedicated to this matter, such as the study by Hiatt et al., which included a number of 1,000 patients who were to receive a liver transplant, suggested a value of $24.3 \%$ for anatomical variants of the hepatic artery (11). A study conducted on 527 donors for liver transplantation identified abnormalities in $30.6 \%$ of cases (12). Chaib advances the figure of $39 \%$, obtained by studying 80 donors (13).

Preoperative evaluation of patients is extremely important, the CT scan with contrast substance being a safe and extremely effective method for highlighting the anatomical variants of the hepatic artery (14), thus allowing a safe surgical approach even in particular situations $(15,16)$. Preoperative imaging diagnosis of possible anatomical variants of the hepatic artery is all the more important in case of patients with concomitant liver disease (17-22).

\section{Conclusions}

The common hepatic artery with retroportal route is an extremely rare anatomical variant. If surgeons do not know of its existence, before or during their surgical intervention, this may lead to a significant risk of important vascular lesions, especially of the portal vein, which can greatly complicate the resection time. Route variants of the hepatic artery are particularly important in liver transplantation surgery, interventional radiology, hepato-pancreatobiliary, gastric oncologic surgery, interventional radiology procedures, but also in trauma surgery, especially supramesocolic abdominal penetrating lesions. Ideally, these anatomical variants should be recognized preoperatively so that the most appropriate surgical approach technique can be adopted.

\section{Conflict of Interest Statement}

The authors declared no potential conflicts of interest with respect to the research, authorship, and/or publication of this article.

\section{Ethical Statement}

The study was conducted respecting the actual ethical principles, with the consent of the health units involved. Informed consent of all patients was obtained and all legal measures were taken to protect personal data. Patients' consent to use the photographs was also obtained.

\section{References}

1. Michels NA. Newer anatomy of the liver and its variant blood supply and collateral circulation. Am J Surg 1966;112:337-47.

2. Hiatt JR, Gabbay J, Busuttil RW. Surgical anatomy of the hepatic arteries in 1000 cases. Ann Surg 1994;220:50-2.

3. Munshi IA, Fusco D, D Tashjian, J R Kirkwood, J Polga, R B Wait. Occlusion of an aberrant right hepatic artery, originating from the superior mesenteric artery, secondary to blunt trauma. J Trauma. 2000;48(2):325-6. 
4. Zaki SM, Abdelmaksoud AHK, Khaled BEA, Abdel Kader IA. Anatomical variations of hepatic artery using the multidetector computed tomography angiography. Folia Morphol 2020;79(2):247-254.

5. Saba L, Mallarini G. Anatomic variations of arterial liver vascularization: an analysis by using MDCTA. Surg Radiol Anat. 2011;33:559-568

6. Vandamme JP, Bonte J, Van der Scheueren G. A reevaluation of hepatic and cystic arteries: The importance of aberrant hepatic branches. Acta Anat. 1969;73:192-209.

7. Suzuki T, Nakayasu A, Kawabe K, Takeda H, Honjo I. Surgical significance of anatomic variations of the hepatic artery. Am J Surg. 1971;122:505-12.

8. Song SY, Chung JW, Yin YH, Jae HJ, Kim HC, Jeon UB, et al. Celiac axis and common hepatic artery variations in 5002 patients: systematic analysis with spiral CT and DSA. Radiology. 2010;255(1):278-88.

9. Sebben GA, Rocha SL, Sebben MA, Parussolo Filho PR, Gonçalves BH Variations of hepatic artery: anatomical study on cadavers. Rev Col Bras Cir. 2013 May-Jun;40(3):221-6.

10. Michels NA. Variational anatomy of the hepatic, cystic, and retroduodenal arteries; a statistical analysis of their origin, distribution, and relations to the biliary ducts in two hundred bodies. AMA Arch Surg. 1953;66(1):20-34

11. Hiatt JR, Gabbay J, Busuttil RW. Surgical anatomy of the hepatic arteries in 1000 cases. Ann Surg. 1994;220(1):50-2

12. Soin AS, Friend PJ, Rasmussen A, Saxena R, Tokat Y, Alexander GJ, et al. Donor arterial variations in liver transplantation: management and outcome of 527 consecutive grafts. Br J Surg. 1996;83(4):637-41.

13. Chaib E. Transplante de fígado: alterações da artéria hepática e do fígado em 80 doadores. Arq gastroenterol. 1993:30(4):82-7.

14. Sureka B, Mittal MK, Mittal A, Sinha M, Bhambri NK, Thukral BB. Variations of celiac axis, common hepatic artery and its branches in 600 patients. Indian J Radiol Imaging. 2013

15. Stanculeanu DL, Ardeleanu CM, Zob DL, Mihaila RI, Toma OC, Simion L, et al. Adenocarcinoma versus pancreatic neuroendocrine tumor - case report, Rom J Morphol Embryol 2017;58(3):1091-1097.

16. Yiming L, Enliang L, Jiaqi M, Chengwu G, Linquan W Rare anatomic variation of the right hepatic artery and accessory right hepatic artery supplying hepatocellular carcinoma. A case report and literature review, Medicine (Baltimore) 2017;96(39): e8144.

17. Ursu RG, Luca CM, Luca AS, Toader E, Simion L, lancu LS. Laboratory Diagnosis for Optimize Therapy of B Hepatitis Virus Infection by Using Biochemical and Molecular Biology Methods, Rev. Chim. 2016; 67(12): 2614-2617.

18. Hanif F, Farooq U, Malik AA, Khan A, Sayyed RH, Niazi IK. Hepatic Artery Variations in a Sample of Pakistani Population. J Coll Physicians Surg Pak. 2020;30(2):187-191.

19. Ionescu S, Bratucu E, Straja ND, Simion L, Marincas M, Prunoiu V, et al. Recurrence rates after radical hysterectomy with pelvic lymphadenectomy, European Journal of Surgical Oncology. 2016:42(9):S158.

20. Carneiro C, Brito J, Bilreiro, C, Barros M, Bahia C, Santiago I, et al. All about portal vein: a pictorial display to anatomy, variants and physiopathology. Insights Imaging. 2019;10(1):38

21. Shin SW. The Current Practice of Transarterial Chemoembolization for the Treatment of Hepatocellular Carcinoma Korean J Radiol. 2009:10(5): 425-434.

22. Zhang W, Wang K, Liu S, Wang Y, Liu K, Meng L, et al. A single-center clinical study of hepatic artery variations in laparoscopic pancreaticoduodenectomy. Medicine (Baltimore). 2020;99(21):e20403 